\title{
Deficit Policy within the Framework of the Stability and Growth Pact: An Empirical Analysis
}

\author{
Nicolas Afflatet ${ }^{1}$ \\ ${ }^{1}$ Department of Public Economics, Helmut-Schmidt-Universität/Universität der Bundeswehr Hamburg, Germany \\ Correspondence: Nicolas Afflatet, Department of Public Economics, Helmut-Schmidt-Universität/Universität der \\ Bundeswehr Hamburg, Germany.
}

Received: December 12, 2016

Accepted: January 4, 2017 Available online: January 10, 2016

doi:10.11114/aef.v4i2.2136

URL: http://dx.doi.org/10.11114/aef.v4i2.2136

\begin{abstract}
It has become common to criticize Germany and France for having broken the Stability and Growth Pact in 2003, supposedly giving way for higher deficits thereafter. However, this question has not yet been answered by the economic literature. It is closely related to the issue whether the Stability and Growth Pact had any disciplining effect on European Monetary Union member countries or not. This article examines the question whether joining the European Monetary Union or the breach of the Stability and Growth Pact in 2003 had an impact on deficits of member states. The empirical analysis shows no evidence for higher deficits after having joined the Eurozone or after having breached the Pact in 2003. These results are robust to different testing methods and when using different data samples. They can be explained with the fact that the Pact was undermined from its beginning and only had a limited disciplining effect henceforth. Otherwise the breakout of the ongoing debt crisis would hardly have been possible.
\end{abstract}

JEL-Classification: E62 Fiscal Policy; H62 Deficit, Surplus

Keywords: stability and growth pact, fiscal rules, deficits, fiscal policy

\section{Introduction}

The debt crisis in the Euro area which erupted in 2010 has still not been completely analyzed in the economic literature. Among others, there is a discussion about Germany's role. After all, Germany was part of the informal coalition which overrode the Stability and Growth Pact (further on simply called the Pact) in 2003. It has been argued that with Germany giving up the commitment to strict fiscal rules other countries would have followed by raising deficits and accumulating high debts (Issing, 2012: 10; Sinn, 2012: 88ff.; Starbatty, 2013: 58ff.). Although it would not be the main reason for the ongoing public debt crisis (Baldwin et al., 2015) it could have been one key element having contributed to it.

Table 1 Deficit Quotas in EMU (1999-2007)

\begin{tabular}{llllllllll}
\hline Ctry & 1999 & 2000 & 2001 & 2002 & 2003 & 2004 & 2005 & 2006 & 2007 \\
\hline BEL & -0.6 & 0.0 & 0.4 & -0.1 & -0.1 & -0.1 & -2.5 & 0.4 & -0.1 \\
DEU & -1.6 & 1.1 & -3.1 & -3.8 & -4.2 & -3.8 & -3.3 & -1.6 & 0.2 \\
IRL & 2.6 & 4.9 & 0.9 & -0.4 & 0.4 & 1.4 & 1.6 & 2.9 & 0.2 \\
GRE & NA & -3.7 & -4.5 & -4.8 & -5.6 & -7.5 & -5.2 & -5.7 & -6.5 \\
ESP & -1.3 & -0.9 & -0.5 & -0.3 & -0.3 & -0.1 & 1.3 & 2.4 & 2.0 \\
FRA & -1.8 & -1.5 & -1.5 & -3.1 & -4.1 & -3.6 & -2.9 & -2.3 & -2.7 \\
ITA & -1.9 & -0.8 & -3.1 & -3.1 & -3.6 & -3.5 & -4.4 & -3.4 & -1.6 \\
LUX & 3.4 & 6.0 & 6.1 & 2.1 & 0.5 & -1.1 & 0.0 & 1.4 & 3.7 \\
NLD & 0.4 & 2.0 & -0.2 & -2.1 & -3.1 & -1.7 & -0.3 & 0.5 & 0.2 \\
AUT & -2.3 & -1.7 & 0.0 & -0.7 & -1.5 & -4.4 & -1.7 & -1.5 & -0.9 \\
PRT & -3.1 & -3.3 & -4.8 & -3.4 & -3.7 & -4.0 & -6.5 & -4.6 & -3.1 \\
FIN & 1.7 & 7.0 & 5.1 & 4.2 & 2.6 & 2.5 & 2.9 & 4.2 & 5.3 \\
\hline
\end{tabular}

Yet, Germany was not alone to violate the Pact. In 2003 five countries in total continually violated the deficit criterion. Especially France and Italy had to expect to be sanctioned, too. But the Excessive Deficit Procedure (EDP) was suspended by the Economic and Financial Affairs Council, the council of the economics and finance ministers of the 
European Union (EU) member states (ECOFIN). ${ }^{1}$ Germany $^{2}$ and France had used their political influence to convince the other governments not to sanction them.

Since then, there has been a considerable amount of violations of the deficit criterion (table 1). Was the breach of the Pact in 2003 the initial dam failure? Or did it already take place earlier: Did the future member countries only commit themselves to consolidation until they had joined the European Monetary Union (EMU)? Both questions shall be treated here empirically and thereby give an answer on the question whether the Pact had a disciplining effect on EMU members.

I am not aware of any studies analyzing the deficit policy of the Euro states in the context of the breach of the Pact in 2003 empirically. This article closes this gap. Based on a panel data analysis, it shows deficits did not fall higher once member countries had joined EMU or after the breaking of the Pact in 2003. These results are robust to different testing methods and when using different data samples. They confirm the existing literature which prevalently states that the Pact only had disciplining effect from the beginning. This can be explained with the Pact's political undermining from the beginning.

The rest of the article is organized as follows: In the second section the literature on the Stability and Growth Pact is reviewed. Theoretical considerations are presented in section 3. A regression analysis is employed to test the two hypotheses, the method and results are presented in section 4 . The results are discussed in more detail in the fifth section containing concluding remarks.

\section{Literature Review}

Several authors already examined fiscal policy within the Maastricht framework empirically, especially in the context of joining EMU. Hagen and Strauch (2001) only find a weak disciplining effect of the Maastricht Treaty for the first half of the nineties. Consolidation successes of the second half must be attributed to the favorable economic conditions.

Lehment (2002) notes that in the first years after the decision to launch the currency union, the countries with the highest deficits reduced them most, but the same is true for non-EMU countries. He also finds that smaller countries showed more success in reducing their deficits. His hypothesis to explain the lack of ambition to lower deficits is that bigger countries run less risk to get sanctioned because of the different voting shares. With Germany having ten and Finland three votes, it would be more difficult to gather a qualified majority to impose sanctioning on the bigger countries. De Haan et al. (2004) explain why bigger countries might choose loose fiscal policies while smaller countries might prefer tight fiscal policies: If a crucial element of the sanction is a loss in political reputation, bigger countries will accept this sanctioning more easily because their loss of reputation will be negligible. Smaller countries however might not be able to bear such damage.

For the first years of EMU, Hagen (2003) shows that there was a considerable degree of consolidation fatigue already. He also points out that the key to achieve the goals of the Pact is a large trend growth rate. Countries with low growth rates (e. g. Germany, France and Italy) should thereby restructure their budgets, lower tax burdens and raise public investments. In the short-run, this would probably lead to a raise in deficits and thereby a violation of the Pact. But sticking to the rules would lead member countries in a situation in which they cannot reform their economies and still suffer from low growth rates. He sees the breach of the Pact in 2003 as a sign that member countries would not accept such a scenario. But he warns that countries should not easily ignore the rules because other states could follow their example.

Busemeyer (2004b) follows a similar question as Lehment (2002): He does not find evidence for an above-average performance of the EU or the EU countries compared to non-EU countries either. But for several single Euro member countries he detects indeed a better fiscal performance, especially for Belgium, Italy and Greece. The Pact thus had some disciplining effect. This confirms his previous research (Busemeyer 2004a) in which he also finds a disciplining effect, at least for smaller EMU countries.

\footnotetext{
${ }^{1}$ The governments concerned argued that the Pact was too rigid and could be interpreted otherwise. It should thereby be reformed. Germany for example suggested to exclude payments to the EU from the deficit calculation, France wanted to exclude military spending and Italy suggested not to take payments for research into account. These measures would have benefited the same countries suggesting them. The reform that was agreed upon in 2005 however did not strengthen the Pact (Feldstein, 2005). The fact that the sanctioning mechanism was not improved is explained by De Haan et al. (2004: 13ff.) with the lack of will to delegate more power from the national states to the EU level.

${ }^{2}$ The German chancellor, Gerhard Schröder, ex-post justified the German policy with the pressure which already laid on the German government because of its reform agenda. To reach a deficit below $3 \%$, the German government would have had to cut down on 20 billion Euro. This was considered to be a too big imposition.
} 
Contrary to several other authors, Annett (2006) judges the fiscal policy under the Stability and Growth Pact to have been an improvement compared to previous outcomes. Especially for the smaller countries the Pact has worked as an anchor which reinforced domestic institutions. Yet, he sees need for further reforms, especially concerning enforcement (crucial in the light of the breaking of the Pact in 2003) and ownership of the Pact. He advocates a shift of responsibility to the member countries so that peer pressure between them is complemented by peer pressure within countries.

By analyzing differences between debt and accumulated deficits, von Hagen and Wolff (2006) find that countries used stock-flow adjustments as a form of creative accounting to hide deficits. They argue that although this creative accounting can be seen in higher debt quotas, governments have an incentive to use this method because greater attention is paid to deficits than to debt quotas. While some countries hardly used this method (e. g. the Netherlands, Belgium or Spain) others extensively did so (e. g. Greece, Finland and Luxembourg). The Pact thus created incentives to bypass it to satisfy its criteria formally.

Finally, Ioannou and Stracca (2011) use a difference-in-difference-approach to analyze the effects of the Stability and Growth Pact. They conclude that it had no overall effect on primary balances other from increasing the sensibility to political business cycles. This result can be read in a positive or a negative manner. Spoken positively, it prevented even higher deficits. But if using a stricter benchmark is used, the SGP has not achieved the goals it was designed for: a greater fiscal discipline among member countries. Yet, they do not take a closer look at the events in 2003.

\section{Theoretical Considerations}

From a theoretical point of view, there are at least two arguments which favor a disciplining effect of the Pact. The first point is peer pressure within EMU: EMU member countries would put pressure on each other so that the stability criteria are met. By denouncing single countries which violate the criteria these countries would indirectly be forced to return to a path of fiscal policy respecting the rules ("naming and shaming"). Direct political pressure of other member countries is another possibility of peer pressure. Hagen (2002) argues that in the first years of EMU it was peer pressure which led to convincing consolidation effects in smaller countries.

The second argument which supports consolidation is market discipline (Bishop et al. 1989, Frenkel and Goldstein, 1991; Lane, 1993). Buti et al. (1998) and de Haan et al. (2004) argue that financial markets would be worried about lasting excessive deficits and would thereby claim higher interest rates. Higher interest rates would then have the same effect as a penalty payment and governments would reduce their deficits as a result (Afflatet, 2015).

However, arguments against a disciplining effect of the Pact can be found, too. One argument is the incentive for free-riding. It has been argued that once member countries have joined EMU, they could benefit from the enlarged leeway and abstain from low deficits because all countries would have to pay for it via an expansive monetary policy which tries to monetize public debt (Beetsma and Bovenberg, 2002; Feldstein, 2005). As we know today, this argument can be extended by the fact that all member countries have to pay for excessive deficits via rescue credits.

The second argument is the poor sanctioning mechanism of the Pact. De Haan et al. (2004) compare the Pact's sanctioning mechanism with budget rules in the federal states of the United States. If governments of US states breach the self-imposed Balanced Budget Rules, courts take over control of the public budget. This possibility does not exist in the Eurozone. Because budgets remain in control of the member states only a fine can be imposed by the Commission and even this fine can still be prevented by member countries.

This opens up the danger of a "tactic of mutual keeping still" (Heinen, 2009: 11), the third argument speaking against the disciplining effect of the Pact. If a member country favors the punishment of an actual sinner, it has to fear that once it violates the criteria itself, the formerly punished country will advocate a punishment in return. No government could be sure not be confronted with the Excessive Deficit Procedure (EDP) one day or another and would as a consequence be cautious when dealing with punishments of their peers.

With arguments found for both sides, the question remains open if the Pact had a disciplining effect. It must be answered empirically.

\section{Empirical Testing}

\subsection{Data}

For the empirical testing a panel containing all 28 countries of the European Union from 1995 to 2015 was assembled. Arbitrarily missing values, especially at the beginning of the time series of the different variables made it an unbalanced panel. With countries joining EMU at different points of time and under different circumstances, the effect of joining EMU on deficits could be analyzed properly.

To test the effects of the breaching of the Pact in 2003, the panel was reduced to the twelve initial member countries because the breaching of the Pact should only have had an effect (if there is one) on these countries because countries being part of the EU but not of EMU - albeit formally bound to the rules of the Pact - do not have to fear sanctioning even if their deficits are too high. 
Different dummies were integrated in both datasets: One dummy designates the country and year when joining EMU (remaining constant thereafter), another one the breaking of the Pact in 2003 (remaining constant thereafter, too). To compare the effects of the two events, these dummies were also employed for the other (sub-)dataset. This approach employing dummies is broadly supported by the literature (Allison, 1994; Woolridge, 2002 and 2012).

As dependent variables, the overall budget and primary balance were employed. The purpose of the budget balance is clear: The Pact aims at the budget balance and requires it to be limited to a deficit quota of $3 \%$. If the Pact had a disciplining effect, member countries should have stuck to this limit. The primary balance is employed as additional dependent variable to examine deficit policy more closely ignoring changing borrowing costs.

The independent variables employed consist of macroeconomic and political variables. A positive economic development certainly has a positive impact on deficits which is the reason why it should be controlled for. After all, it could be argued e. g. that deficits after having joined EMU or after the breaking of the Pact were higher because growth rates fell. This possibility is especially relevant because the time covered includes the financial crisis from 2008 and later on the debt crisis from 2010 onwards. Both crises entailed lower growth and consequently higher deficits. By including the macroeconomic variables, it is made sure that these changes are taken into account. To take the negative impact of the financial crisis and the debt crisis into account, a dummy for the GIPSCI countries (Greece, Ireland, Portugal, Spain, Cyprus and Italy who all were severely struck by the crises) was also included.

Political variables have also been proven to show an impact on deficits. That is why they were employed as different dummies: a dummy for national parliamentary election years ${ }^{3}$, a dummy for left parties in government ${ }^{4}$ and a dummy for coalition governments. ${ }^{5}$ An overview of the cardinal variables is given in table 2 .

The boxplots in figure 1 give a first impression about deficits and primary surpluses of EMU and non-EMU countries (both measured as quotas relative to the national GDP). For both variables considered there seems to be no striking difference between EMU members and non-EMU members. The medians of the deficits and primary surpluses of EMU member countries both lie well within the range of the medium quartiles of non-EMU member countries.

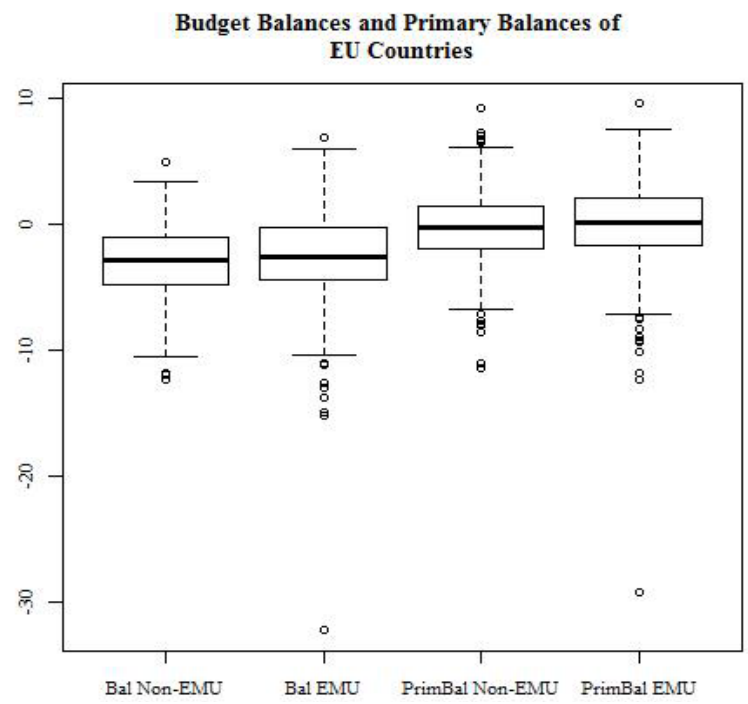

Figure 1. Deficits and Primary Surpluses of EU Countries (1995-2015)

\footnotetext{
${ }^{3}$ The theory of political business (or budget) cycles states that governments have an incentive to raise deficits at the eve of elections in order to raise their probability election, given the Barro-Ricardo equivalence does not hold. Yet, the empirical evidence is not entirely clear and it seems to play a role which kind of country is considered (Brender and Drazen, 2005; Alt and Lassen, 2006; Brender and Drazen, 2008; Jong-A-Pin, Sturm and de Haan, 2012).

${ }^{4}$ According to the theory of partisan business cycles, left governments prefer higher deficits over unemployment. That is why it has been widely tested which influence the color of the government has on deficits, yet without unambiguous results (Perotti and Kontopoulos, 1999; Volkerink and de Haan, 2000).

${ }^{5}$ Roubini and Sachs (1989) find that coalition governments tend to show higher deficits because in a coalition each party has a right to veto with which it protects its partisans. That is their explanation why coalition governments prefer to raise deficits. Their thesis has been further discussed (Volkerink and de Haan, 2000; Perotti and Kontopoulos, 2002), not without having been contradicted (Edin and Ohlsson, 1991).
} 
For the sub-dataset for the twelve initial EMU members, the situation is somewhat different (Figure 2). Again, there seems to be no particular difference concerning deficits up to 2003 and afterwards. But the primary surpluses clearly show a difference before and after 2003. The median for the years after 2003 lies outside the range of the quartiles of the years up to 2003. Hence, we find some evidence that primary surpluses were smaller after the breach of the Pact in 2003. But with the Pact demanding deficits below 3\%, this cannot be seen as an argument that the breaching in 2003 had an impact on deficits of member states.

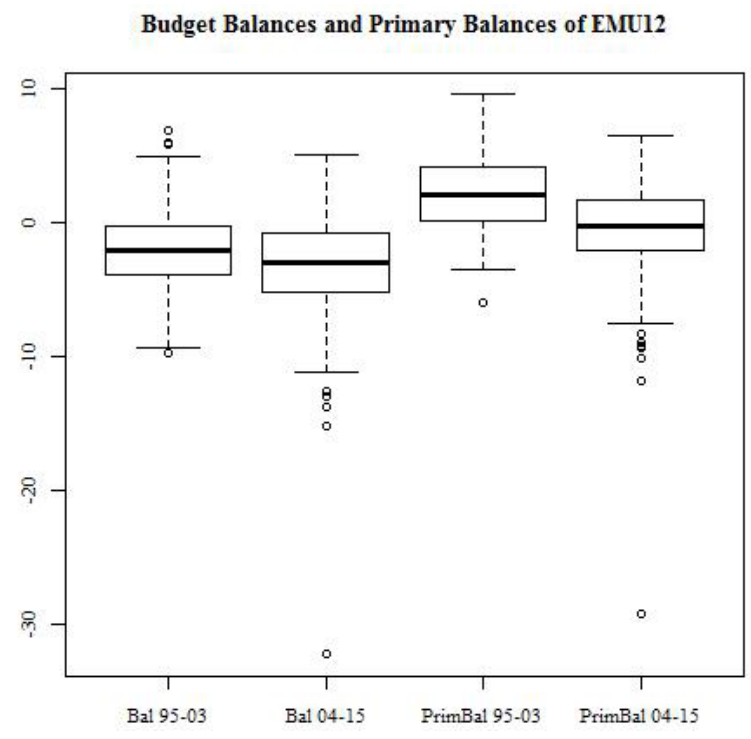

Figure 2. Deficits and Primary Surpluses of EMU Countries (1995-2015)

\subsection{Econometric Method}

A regression with individual fixed effects ${ }^{6}$ was run to evaluate the effect of joining EMU and the breaking of the Pact on public balance figures. Two different types of models were formulated: One with the primary balance $\left(s_{t, t}\right)$ as dependent variable (models $1,3,5,7$ ), the other one with the national deficit (or budget balance, $b_{t, t}$ ) as dependent variable (models 2, 4, 6, 8). They were tested with once the dummy for joining EMU (MembEuro, models 1, 2, 3, 4) and once with the dummy for the breaking of the Pact in 2003 (BreakingPact, models 5, 6, 7, 8) as independent variables of interest.

$$
\begin{gathered}
s_{t, t}=\beta_{0} \text { MembEuro }_{t}+\beta_{1} X_{t, t}+\alpha_{t}+u_{t, t}(\text { models } 1 \text { and } 3) \\
s_{t, t}=\beta_{0} \text { BreakingPact }_{t}+\beta_{1} X_{t, t}+\alpha_{t}+u_{t, t}(\text { models } 5 \text { and } 7) \\
b_{t, t}=\beta_{0} \text { MembEuro }_{t}+\beta_{1} X_{t, t}+\alpha_{t}+u_{t, t}(\text { models } 2 \text { and } 4) \\
\left.b_{t, t}=\beta_{0} \text { BreakingPact }_{t}+\beta_{1} X_{t, t}+\alpha_{t}+u_{t, t} \text { (models } 6 \text { and } 8\right)
\end{gathered}
$$

In all regressions, $X_{t . t}$ catches the covariates, $\alpha_{t}$ catches the unobserved variables which differ across the countries but remain constant over time, $u_{t, t}$ is the error term.

The first four models were used to analyze deficit policy before and after joining EMU. However, there might be a selection problem for the first dataset, e. g. that only the countries with low deficits would have been allowed to enter EMU. That is why this problem was also addressed for the sub-dataset only containing the twelve initial member states for which this problem is not at hand (models 7 and 8).

A similar problem appears for the models 5 to 8 with which public budget balances before and after the breaking of the Pact were examined: It could be argued that if there is a difference in deficits before and after 2003 it could be due to some structural reasons that have nothing to do with the intended deficit policy of the member states, e. g. due to the financial crisis in 2008 or a structural change in interest rates. That is why the dummy for the breaking of the Pact in 2003 was also applied to the dataset of the entire EU (models 3 and 4).

\footnotetext{
${ }^{6}$ The Hausman-test could not reject the null for all eight models. But from an economic point of view, the use of fixed effects seems justified. Additionally, the results did not substantially change when using random instead of fixed effects.
} 


\subsection{Regression Results}

The results of the regression analysis are indicated in table 3.

The EMU membership dummy is only significant in one case (model 4). Otherwise joining EMU seems not to have affected the primary (1) or budget balance (2). The same is true when considering only the twelve initial members of EMU (models 7 and 8). Furthermore, when controlling for the breaking of the pact in 2003 (3), primary surpluses seem to have been higher after having joined EMU, but again, the coefficient is not significant. We can't conclude that primary balances have been affected by joining EMU.

For the overall budget balance, the situation is similar: The coefficient is not significant (2) albeit robust (table 6). It becomes significant when controlling for the breaking of the pact in 2003 (4) and the algebraic sign is even positive. Yet, when considering the twelve initial members (8) and controlling for the breaking of the Pact, the coefficient is not significant either. This leads to the conclusion that there is only limited evidence that deficits of countries having joined EMU were lower, but it is certainly not a reliable result. From these results we cannot conclude that joining EMU would have affected public primary or overall budget balances.

For the first four models (1-4), the coefficient for national parliamentary elections is significant but only at the $10 \%$ level. Thus, parliamentary elections could have some minor influence on budget balances. The composition of the government on the other side does not seem to matter for deficits. A positive macroeconomic development with higher growth and lower unemployment clearly has positive influence on budget and primary balances, whereas the real exchange rate does not. Finally, the dummy for Greece, Ireland, Portugal, Spain, Cyprus and Italy (GIPSCI) indicates that primary and budget balances were significantly affected for these countries from 2010 to 2015.

Concerning the breaking of the Pact in 2003, the results are more difficult to evaluate. Deficits seem to not have been negatively affected by it: The coefficients of the models 6 and 8 are all negative, yet neither robust (table 6) nor significant. Primary balances, however, were lower after 2003 (models 5 and 7, yet not significant for the latter). Though, the fact that the dummy for the entire EU is also negative, significant (3) and robust (table 6) leads to the conclusion that deficits were not affected by the breaking of the pact in 2003 but primary balances in the entire European Union seem to have deteriorated after 2003.

Neither election years nor left parties in government seem to have had an influence on public balances in the EMU12. Interestingly, the coefficient for coalition governments is significant at the $1 \%$ level in all four models (5-8). Coalition governments clearly seem to have shown lower budget deficits and primary deficits, thereby contradicting the results of Roubini and Sachs (1989).

Again, a positive macroeconomic development with higher growth and lower unemployment rates clearly has a positive impact on public balances. And so does the real exchange rate: The higher the index for the real exchange rate, the higher deficits and primary deficits. This was not the case for the entire European Union but it seems to be for the Euro area with the coefficients being significant at the $0.1 \%$ level. Given that the European debt crisis is among others a problem of lost competitiveness (Sinn, 2014; Baldwin et al., 2015), this is not surprising.

\subsection{Model Analysis}

Two tests to compare the results of the regression with fixed effects to other panel estimation methods were performed (table 4). The F-test comparing a pooled model with one with fixed effects clearly rejects the null for all models. The use of fixed effects is thus justified. Still, the OLS results do not put the results of the fixed effects regressions into question.

The Hausman test does not reject the null in all cases. From an economic point of view, it is justified to use fixed effects. Again, the results of the regressions with random effects (table 5) do not put the results presented above into question. This is also true for the estimations with $\mathrm{M}$ estimators (table 6) which confirm the results presented above.

\section{Concluding Remarks}

The results of the empirical analysis show that deficit policy did not significantly change once EMU countries had joined the currency union. Concerning the breaching of the Stability Pact in 2003, no significant change in deficits can be assessed either. Therefore, it must be concluded that deficits were not affected by both events. These results are in line with former results which had already shown that the Pact only had a limited disciplining effect at best.

It could be argued in a benevolent manner that deficits could have fallen bigger if member countries had not been bound by the Pact. It would then indeed have had a disciplining effect. But this view is questionable. The Pact aimed at limiting the deficits to $3 \%$ and debt to $60 \%$. A look at the data shows that this aim has clearly been missed. With the falling growth rates since the start of EMU and especially since the financial crisis of 2008, deficits would have had to be well below $3 \%$ to reach a sustainable debt situation at a debt quota of $60 \%$. 
The empirical results above contradict prevalent assumptions. Especially the fact that the breach of the Pact in 2003 did not lead to rising deficits is surprising at first sight. This result can still be explained if the perspective is changed : I argue that the Pact could not be broken in 2003 because it had decisively been broken much earlier and had only a limited disciplining effect henceforth.

Before the start of EMU already, several countries did not fulfill the criteria formulated in the Maastricht treaty: Belgium and Italy were accepted as members although they clearly exceeded the $60 \%$ debt criterion. Germany's debt quota exceeded the critical value from 1998 on, too. To make the economic criterion fit the political requirement, the criteria were politically interpreted. For Belgium and Italy, a passage demanding a declining debt quota was introduced (Issing, 2008: 11ff.), for Germany the costs of the reunification were excluded from the calculation.

A similar pattern can be found for the deficit criterion: To meet it, several countries used tricks to reduce their actual deficits. Germany sold stocks of the Deutsche Telekom and the Deutsche Post, France took over pension obligations from France Télécom and Italy introduced a refundable Euro tax. The Greek example is especially striking in this context. Table 1 shows that it never fulfilled the deficit criterion and yet it was never sanctioned. One reason is that it successfully manipulated its statistics (Moog and Raffelhüschen, 2011: 10). Yet, other countries used methods of creative accounting to hide deficits, too (Hagen and Wolff, 2006).

These early bypassings of the Pact are evidence of the inconsistency problem of optimal plans (Kydland and Prescott, 1977). When EMU was designed it seemed advisable (especially for Germany) to claim strict criteria to guarantee that all countries would follow the German objective of price stability and low deficits. ${ }^{7}$ But if all criteria had been respected, the currency union would never have been founded as it was desired. As a result, the criteria were eased to achieve the political goals - regardless of future costs. The optimal plan set before was abandoned because it seemed politically obstructive. This way, a new agenda for EMU was set: The criteria should still be valid formally but in practice violations of the rules would be handled with great neglect.

The regression analysis above also showed that primary surpluses fell after 2003. If deficits remained unchanged in both cases but primary surpluses were smaller, there must have been a substantial change in interest costs. Figure 3 confirms this point: It shows that interest quotas (public interest payments as a share of GDP) fell from 1995 onwards, just as interest rates on the accumulated debt. This was a result of the summit of Madrid when the composition of EMU was fixed (Sinn, 2012: 75ff.). Interest rates converged to the German level once it was clear which countries would be part of EMU. ${ }^{8}$

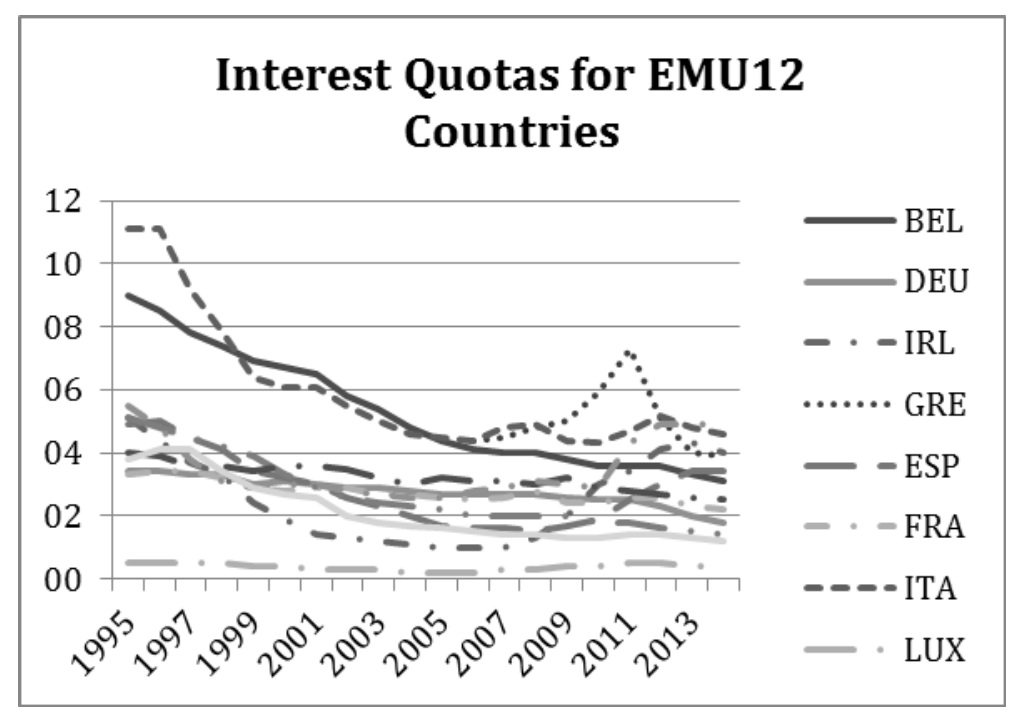

Figure 3. Interest Quotas in EMU (1995-2014)

\footnotetext{
${ }^{7}$ The debt and deficit criterion do not primarily aim at the functioning of a monetary union. They rather aim especially at the German voters' (and politicians') fear that the value of the new currency could be weakened by an inflation-friendly central bank which eases financing problems of member states. This fear is a result of historical experiences, especially of the Hyperinflation 1923 which was the result of a state unable to cover its additional expenses.

${ }^{8}$ Feldstein (2005) explains this with the faith of financial markets in a bail-out in case one member state would succumb to a debt crisis.
} 
Sinn (2012: 80ff.) has shown for Italy that governments preferred to spend the money saved on interest payments for other purposes instead to reduce its debt in a more determined manner. ${ }^{9}$ The regression analysis above shows that a general argument can be made out of this. Whereas deficits remained unaffected by joining EMU and the breaking of the Pact in 2003, primary balances distinctly deteriorated after 2003 as a result of falling interest payments. Member countries benefitting from the decline in interest payments could have used the money to reduce their deficits and debt quotas. Such a policy would have corresponded to the spirit of the Pact. But only Ireland and Spain did so to a substantial degree. Most other member countries preferred to enjoy the enlarged fiscal leeway.

\section{Annex}

Table 2. Descriptive Statistics of the Dataset European Union

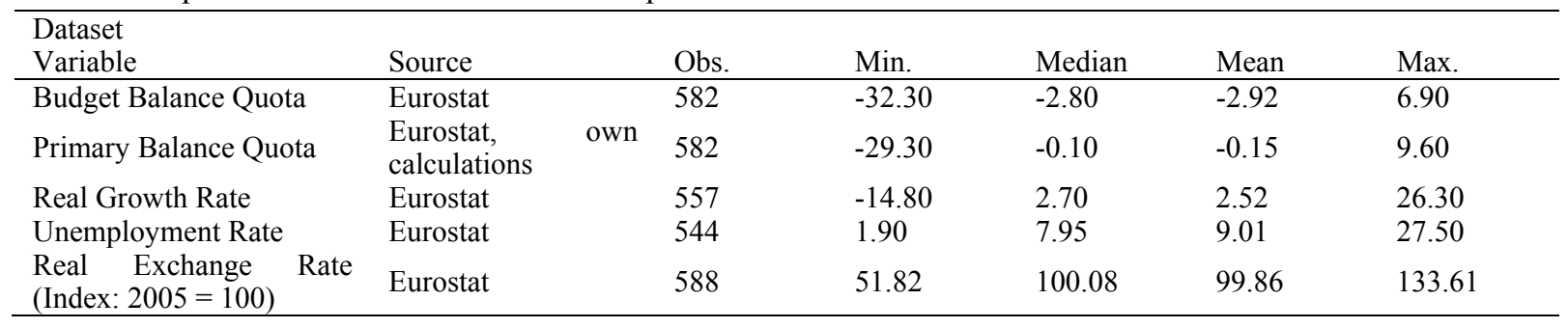

Table 3. Regression Analysis with Fixed Effects ${ }^{10}$

\begin{tabular}{|c|c|c|c|c|c|c|c|c|}
\hline & $\begin{array}{l}\text { 1) Primary } \\
\text { Balance } \\
\text { Fixed } \\
\text { Effects }\end{array}$ & $\begin{array}{l}\text { 2) Budget } \\
\text { Balance } \\
\text { Fixed } \\
\text { Effects }\end{array}$ & $\begin{array}{l}\text { 3) Primary } \\
\text { Balance } \\
\text { Fixed } \\
\text { Effects }\end{array}$ & $\begin{array}{l}\text { 4) Budget } \\
\text { Balance } \\
\text { Fixed } \\
\text { Effects }\end{array}$ & $\begin{array}{l}\text { 5) Primary } \\
\text { Balance } \\
\text { Fixed } \\
\text { Effects }\end{array}$ & $\begin{array}{l}\text { 6) Budget } \\
\text { Balance } \\
\text { Fixed } \\
\text { Effects }\end{array}$ & $\begin{array}{l}\text { 7) Primary } \\
\text { Balance } \\
\text { Fixed } \\
\text { Effects }\end{array}$ & $\begin{array}{l}\text { 8) Budget } \\
\text { Balance } \\
\text { Fixed } \\
\text { Effects }\end{array}$ \\
\hline Member EMU & $\begin{array}{l}-0.31 \\
(-0.86)\end{array}$ & 0.67 (1.91). & $0.25(0.64)$ & $\begin{array}{l}0.87 \\
(2.35)^{*}\end{array}$ & & & $\begin{array}{l}-0.32 \\
(-0.53)\end{array}$ & $0.82(1.40)$ \\
\hline Breaking Pact & & & & & $\begin{array}{l}-1.38 \\
(-3.49)^{* * *}\end{array}$ & $\begin{array}{l}-0.16 \\
(-0.42)\end{array}$ & $\begin{array}{l}-1.26 \\
(-2.74)^{* *}\end{array}$ & $\begin{array}{l}-0.48 \\
(-1.07)\end{array}$ \\
\hline Dummy 2003 & & & $\begin{array}{l}-1.29 \\
(-4.64)^{* * *}\end{array}$ & $\begin{array}{l}-0.46 \\
(-1.69)\end{array}$ & & & & \\
\hline Election Year & $\begin{array}{l}-0.47 \\
(-1.85)\end{array}$ & $\begin{array}{l}-0.47 \\
(-1.94) .\end{array}$ & $\begin{array}{l}-0.46 \\
(-1.84)\end{array}$ & $\begin{array}{l}-0.47 \\
(-1.93)\end{array}$ & $\begin{array}{l}-0.38 \\
(-0.96)\end{array}$ & $\begin{array}{l}-0.38 \\
(-0.99)\end{array}$ & $\begin{array}{l}-0.37 \\
(-0.95)\end{array}$ & $\begin{array}{l}-0.39 \\
(-1.01)\end{array}$ \\
\hline $\begin{array}{l}\text { Government } \\
\text { Including Left } \\
\text { Party }\end{array}$ & $\begin{array}{l}0.17 \\
(0.69)\end{array}$ & $\begin{array}{l}-0.15 \\
(-0.64)\end{array}$ & $0.05(0.20)$ & $\begin{array}{l}-0.20 \\
(-0.82)\end{array}$ & $0.18(0.44)$ & $\begin{array}{l}-0.14 \\
(-0.35)\end{array}$ & $0.16(0.37)$ & $\begin{array}{l}-0.08 \\
(-0.19)\end{array}$ \\
\hline $\begin{array}{l}\text { Coalition } \\
\text { Government }\end{array}$ & $\begin{array}{l}0.19 \\
(0.42)\end{array}$ & $0.66(1.50)$ & $0.43(0.95)$ & 0.74 (1.69). & $\begin{array}{l}2.41 \\
(2.97)^{* *}\end{array}$ & $\begin{array}{l}3.29 \\
(4.10)^{* * * *}\end{array}$ & $\begin{array}{l}2.45 \\
(3.01)^{* *}\end{array}$ & $\begin{array}{l}3.18 \\
(3.94)^{* * *}\end{array}$ \\
\hline Growth & $\begin{array}{l}0.34 \\
(9.50)^{* * *}\end{array}$ & $\begin{array}{l}0.34 \\
(10.00)^{* * *}\end{array}$ & $\begin{array}{l}0.32 \\
(9.16)^{* * *}\end{array}$ & $\begin{array}{l}0.34 \\
(9.79)^{* * *}\end{array}$ & $\begin{array}{l}0.28 \\
(4.26)^{* * *}\end{array}$ & $\begin{array}{l}0.26 \\
(4.03) * * *\end{array}$ & $\begin{array}{l}0.27 \\
(4.04) * * *\end{array}$ & $\begin{array}{l}0.28 \\
(4.24) * * *\end{array}$ \\
\hline Unemployment & $\begin{array}{l}-0.14 \\
(-2.86)^{* *}\end{array}$ & $\begin{array}{l}-0.23 \\
(-5.06)^{* * *}\end{array}$ & $\begin{array}{l}-0.17 \\
(-3.46)^{* * *}\end{array}$ & $\begin{array}{l}-0.25 \\
(-5.24)^{* * *}\end{array}$ & $\begin{array}{l}-0.22 \\
(-2.75)^{* *}\end{array}$ & $\begin{array}{l}-0.38 \\
(-4.64)^{* * *}\end{array}$ & $\begin{array}{l}-0.24 \\
(-2.77)^{* *}\end{array}$ & $\begin{array}{l}-0.34 \\
(3.95)^{* * *}\end{array}$ \\
\hline $\begin{array}{l}\text { Real Exchange } \\
\text { Rate }\end{array}$ & $\begin{array}{l}-0.02 \\
(-1.22)\end{array}$ & $0.00(0.29)$ & $0.01(0.40)$ & $0.01(0.85)$ & $\begin{array}{l}-0.29 \\
(-4.80)^{* * *}\end{array}$ & $\begin{array}{l}-0.26 \\
(-4.42)^{* * *}\end{array}$ & $\begin{array}{l}-0.29 \\
(-4.80) * * *\end{array}$ & $\begin{array}{l}-0.24 \\
(-4.08)^{* * *}\end{array}$ \\
\hline GIPSCI & $\begin{array}{l}-1.61 \\
(-2.47)^{*}\end{array}$ & $\begin{array}{l}-1.50 \\
(-2.40)^{*}\end{array}$ & $\begin{array}{l}-1.06 \\
(-1.63)\end{array}$ & $\begin{array}{l}-1.30 \\
(-2.05)^{*}\end{array}$ & $\begin{array}{l}-0.39 \\
(-4.45)\end{array}$ & $\begin{array}{l}-0.46 \\
(-0.54)\end{array}$ & $\begin{array}{l}-0.27 \\
(-0.31)\end{array}$ & $\begin{array}{l}-0.75 \\
(-0.87)\end{array}$ \\
\hline $\mathrm{N}$ & 532 & 532 & 532 & 532 & 532 & 241 & 241 & 241 \\
\hline $\mathrm{R}^{2}$ & 0.26 & 0.29 & 0.28 & 0.30 & 0.42 & 0.40 & 0.41 & 0.40 \\
\hline
\end{tabular}

Table 4. Model Analysis

\begin{tabular}{llllllllll}
\hline & 1) Primary & 2) Budget & 3) Primary & 4) Budget & 5) Primary & 6) Budget & 7) Primary & 8) Budget \\
& Balance & Balance & Balance & Balance & Balance & Balance & Balance & Balance \\
\hline \multirow{2}{*}{ F test } & $\mathrm{F}=8.26$ & $\mathrm{~F}=8.81$ & $\mathrm{~F}=7.94$ & $\mathrm{~F}=8.75$ & $\mathrm{~F}=8.03$ & $\mathrm{~F}=9.99$ & $\mathrm{~F}=7.98$ & $\mathrm{~F}=9.29$ \\
Hausman & $\mathrm{p}=0,00$ & $\mathrm{p}=0,00$ & $\mathrm{p}=0,00$ & $\mathrm{p}=0,00$ & $\mathrm{p}=0,00$ & $\mathrm{p}=0,00$ & $\mathrm{p}=0,00$ & $\mathrm{p}=0.00$ \\
test & $\mathrm{X}^{2}=14.22$ & $\mathrm{X}^{2}=6.57$ & $\mathrm{X}^{2}=6.25$ & $\mathrm{X}^{2}=6.56$ & $\mathrm{X}^{2}=13.44$ & $\mathrm{X}^{2}=20.05$ & $\mathrm{X}^{2}=5.49$ & $\mathrm{X}^{2}=14.03$ \\
& $\mathrm{p}=0.07$ & $\mathrm{p}=0.58$ & $\mathrm{p}=0.71$ & $\mathrm{p}=0.68$ & $\mathrm{p}=0.10$ & $\mathrm{p}=0.02$ & $\mathrm{p}=0.86$ & $\mathrm{p}=0.12$ \\
\hline
\end{tabular}

\footnotetext{
${ }^{9}$ Had Italy used the saved interest to lower its debt quota, it would be at around 13\% today (Sinn, 2014: 3).

${ }^{10} 10 \%$ confidence interval; $* 5 \%$ confidence interval; $* * 1 \%$ confidence interval; $* * * 0.1 \%$ confidence interval.
} 
Table 4. Regression Analysis with Random Effects ${ }^{11}$

\begin{tabular}{|c|c|c|c|c|c|c|c|c|}
\hline & $\begin{array}{l}\text { 1) Primary } \\
\text { Balance }\end{array}$ & $\begin{array}{l}\text { 2) Budget } \\
\text { Balance }\end{array}$ & $\begin{array}{l}\text { 3) Primary } \\
\text { Balance }\end{array}$ & $\begin{array}{l}\text { 4) Budget } \\
\text { Balance }\end{array}$ & $\begin{array}{l}\text { 5) Primary } \\
\text { Balance }\end{array}$ & $\begin{array}{l}\text { 6) Budget } \\
\text { Balance }\end{array}$ & $\begin{array}{l}\text { 7) Primary } \\
\text { Balance }\end{array}$ & $\begin{array}{l}\text { 8) Budget } \\
\text { Balance }\end{array}$ \\
\hline & Random & Random & Random & Random & Random & Random & Random & Random \\
\hline & Effects & Effects & Effects & Effects & Effects & Effects & Effects & Effects \\
\hline Intercept & $2.37(1.48)$ & $\begin{array}{l}-3.10 \\
(-2.01)^{*}\end{array}$ & $0.59(0.37)$ & $\begin{array}{l}-3.69 \\
(-2.34)^{*}\end{array}$ & $\begin{array}{l}27.49 \\
(4.67)^{* * *}\end{array}$ & $\begin{array}{l}22.38 \\
(3.83)^{* * *}\end{array}$ & $\begin{array}{l}25.73 \\
(4.16)^{* * *}\end{array}$ & $\begin{array}{l}19.47 \\
(3.21)^{* *}\end{array}$ \\
\hline Member EMU & $\begin{array}{l}-0.08 \\
(-0.24)\end{array}$ & $\begin{array}{l}0.65 \\
(1.97)^{*}\end{array}$ & $0.41(1.17)$ & $\begin{array}{l}0.82 \\
(2.39)^{*}\end{array}$ & & & $\begin{array}{l}-0.03 \\
(-0.05)\end{array}$ & $\begin{array}{l}0.99 \\
(1.69) .\end{array}$ \\
\hline Breaking Pact & & & & & $\begin{array}{l}-1.40 \\
(-3.52)^{* * *}\end{array}$ & $\begin{array}{l}-0.16 \\
(-0.41)\end{array}$ & & \\
\hline Dummy 2003 & & & $\begin{array}{l}-1.36 \\
(-4.98)^{* * *}\end{array}$ & $\begin{array}{l}-0.46 \\
(-1.74)\end{array}$ & & & $\begin{array}{l}-1.40 \\
(-2.98)^{* *}\end{array}$ & $\begin{array}{l}-0.54 \\
(-1.20)\end{array}$ \\
\hline Election Year & $\begin{array}{l}-0.47 \\
(-1.86) .\end{array}$ & $\begin{array}{l}-0.48 \\
(-1.97)^{*}\end{array}$ & $\begin{array}{l}-0.46 \\
(-1.84)\end{array}$ & $\begin{array}{l}-0.47 \\
(-1.95)\end{array}$ & $\begin{array}{l}-0.38 \\
(-0.96)\end{array}$ & $\begin{array}{l}-0.38 \\
(-0.99)\end{array}$ & $\begin{array}{l}-0.38 \\
(-0.94)\end{array}$ & $\begin{array}{l}-0.39 \\
(-1.02)\end{array}$ \\
\hline $\begin{array}{l}\text { Government } \\
\text { Including Left } \\
\text { Party }\end{array}$ & $0.24(0.99)$ & $\begin{array}{l}-0.14 \\
(-0.58)\end{array}$ & $0.10(0.40)$ & $\begin{array}{l}-0.18 \\
(-0.78)\end{array}$ & $0.22(0.55)$ & $\begin{array}{l}-0.11 \\
(-0.28)\end{array}$ & $0.26(0.62)$ & $\begin{array}{l}-0.04 \\
(-0.09)\end{array}$ \\
\hline $\begin{array}{l}\text { Coalition } \\
\text { Government }\end{array}$ & $0.27(0.67)$ & $\begin{array}{l}0.81 \\
(2.04)^{*}\end{array}$ & $0.48(1.18)$ & $\begin{array}{l}0.88 \\
(2.21)^{*}\end{array}$ & $\begin{array}{l}2.19 \\
(3.21)^{* *}\end{array}$ & $\begin{array}{l}2.89 \\
(4.14)^{* * *}\end{array}$ & $\begin{array}{l}2.14 \\
(3.39)^{* * *}\end{array}$ & $\begin{array}{l}2.81 \\
(4.04)^{* * *}\end{array}$ \\
\hline Growth & $\begin{array}{l}0.33 \\
(9.42)^{* * *}\end{array}$ & $\begin{array}{l}0.34 \\
(10.27)^{* * *}\end{array}$ & $\begin{array}{l}0.31 \\
(9.08)^{* * *}\end{array}$ & $\begin{array}{l}0.34 \\
(10.05)^{* * *}\end{array}$ & $\begin{array}{l}0.28 \\
(4.20)^{* * *}\end{array}$ & $\begin{array}{l}0.27 \\
(4.17)^{* * *}\end{array}$ & $\begin{array}{l}0.27 \\
(3.97)^{* * *}\end{array}$ & $\begin{array}{l}0.29 \\
(4.45) * * *\end{array}$ \\
\hline Unemployment & $\begin{array}{l}-0.16 \\
(-3.56) * * *\end{array}$ & $\begin{array}{l}-0.23 \\
(-5.50)^{* * *}\end{array}$ & $\begin{array}{l}-0.18 \\
(-4.13)^{* * *}\end{array}$ & $\begin{array}{l}-0.24 \\
(-5.67)^{* * *}\end{array}$ & $\begin{array}{l}-0.17 \\
(-2.38)^{*}\end{array}$ & $\begin{array}{l}-0.32 \\
(-4.36)^{* * *}\end{array}$ & $\begin{array}{l}-0.14 \\
(-1.96)\end{array}$ & $\begin{array}{l}-0.28 \\
(-3.65)^{* * *}\end{array}$ \\
\hline $\begin{array}{l}\text { Real Exchange } \\
\text { Rate }\end{array}$ & $\begin{array}{l}-0.02 \\
(-1.46)\end{array}$ & $0.01(0.73)$ & $\begin{array}{l}0.01 \\
(-1.60)\end{array}$ & $0.02(1.29)$ & $\begin{array}{l}-0.27 \\
(-4.56)^{* * *}\end{array}$ & $\begin{array}{l}-0.25 \\
(-4.23) * * *\end{array}$ & $\begin{array}{l}-0.25 \\
(-4.17) * * *\end{array}$ & $\begin{array}{l}-0.23 \\
(-3.83) * * *\end{array}$ \\
\hline GIPSCI & $\begin{array}{l}-1.55 \\
(-2.47)^{*}\end{array}$ & $\begin{array}{l}-1.66 \\
(-2.76)^{* *}\end{array}$ & $\begin{array}{l}-1.00 \\
(-1.60)\end{array}$ & $\begin{array}{l}-1.47 \\
(-2.41)^{*}\end{array}$ & $\begin{array}{l}-0.84 \\
(-1.00)\end{array}$ & $\begin{array}{l}-0.86 \\
(-1.03)\end{array}$ & $\begin{array}{l}-1.17 \\
(-1.36)\end{array}$ & $\begin{array}{l}-1.19 \\
(-1.39)\end{array}$ \\
\hline $\mathrm{N}$ & 532 & 532 & 532 & 532 & 241 & 241 & 241 & 241 \\
\hline $\mathrm{R}^{2}$ & 0.26 & 0.31 & 0.29 & 0.32 & 0.42 & 0.41 & 0.41 & 0.42 \\
\hline
\end{tabular}

Table 6. Robustness Check

\begin{tabular}{|c|c|c|c|c|c|c|c|c|}
\hline & $\begin{array}{l}\text { 1) Primary } \\
\text { Balance } \\
\mathrm{M} \\
\text { Estimator }\end{array}$ & $\begin{array}{l}\text { 2) Budget } \\
\text { Balance } \\
\mathrm{M} \\
\text { Estimator }\end{array}$ & $\begin{array}{l}\text { 3) Primary } \\
\text { Balance } \\
\mathrm{M} \\
\text { Estimator }\end{array}$ & $\begin{array}{l}\text { 4) Budget } \\
\text { Balance } \\
\mathrm{M} \\
\text { Estimator }\end{array}$ & $\begin{array}{l}\text { 5) Primary } \\
\text { Balance } \\
\mathrm{M} \\
\text { Estimator }\end{array}$ & $\begin{array}{l}\text { 6) Budget } \\
\text { Balance } \\
\mathrm{M} \\
\text { Estimator }\end{array}$ & $\begin{array}{l}\text { 7) Primary } \\
\text { Balance } \\
\mathrm{M} \\
\text { Estimator }\end{array}$ & $\begin{array}{l}\text { 8) Budget } \\
\text { Balance } \\
\mathrm{M} \\
\text { Estimator }\end{array}$ \\
\hline Intercept & $2.26(1.69)$ & $\begin{array}{l}-6.50 \\
(-5.30)\end{array}$ & $\begin{array}{l}-0.07 \\
(-0.05)\end{array}$ & $\begin{array}{l}-7.39 \\
(-5.94)\end{array}$ & $\begin{array}{l}16.52 \\
(3.52)\end{array}$ & $6.28(1.36)$ & $\begin{array}{l}15.55 \\
(3.21)\end{array}$ & $1.77(0.38)$ \\
\hline Member EMU & $0.70(2.82)$ & $0.75(3.27)$ & $0.96(3.90)$ & $0.83(3.65)$ & & & $0.38(0.75)$ & $1.66(3.41)$ \\
\hline Breaking Pact & & & & & $\begin{array}{l}-1.30 \\
(-3.75)\end{array}$ & $0.08(0.25)$ & & \\
\hline Dummy 2003 & & & $\begin{array}{l}-1.55 \\
(-5.87)\end{array}$ & $\begin{array}{l}-0.58 \\
(-2.34)\end{array}$ & & & $\begin{array}{l}-1.45 \\
(-3.65)\end{array}$ & $\begin{array}{l}-0.57 \\
(-1.48)\end{array}$ \\
\hline Election Year & $\begin{array}{l}-0.54 \\
(-2.08)\end{array}$ & $\begin{array}{l}-0.51 \\
(-2.16)\end{array}$ & $\begin{array}{l}-0.50 \\
(-2.01)\end{array}$ & $\begin{array}{l}-0.50 \\
(-2.12)\end{array}$ & $\begin{array}{l}-0.48 \\
(-1.40)\end{array}$ & $\begin{array}{l}-0.39 \\
(-1.16)\end{array}$ & $\begin{array}{l}-0.49 \\
(-1.43)\end{array}$ & $\begin{array}{l}-0.47 \\
(-1.44)\end{array}$ \\
\hline $\begin{array}{l}\text { Government } \\
\text { Including Left } \\
\text { Party }\end{array}$ & $0.58(2.47)$ & $0.08(0.39)$ & $0.48(2.09)$ & $0.03(0.14)$ & $0.47(1.42)$ & $0.00(0.01)$ & $0.51(1.54)$ & $0.15(0.48)$ \\
\hline $\begin{array}{l}\text { Coalition } \\
\text { Government }\end{array}$ & $0.42(1.45)$ & $1.04(4.03)$ & $0.54(1.97)$ & $1.09(4.29)$ & $2.56(6.26)$ & $2.43(6.04)$ & $2.56(6.31)$ & $2.40(6.14)$ \\
\hline Growth & $0.28(8.41)$ & $\begin{array}{l}0.38 \\
(12.60)\end{array}$ & $0.26(8.12)$ & $\begin{array}{l}0.38 \\
(12.54)\end{array}$ & $0.27(4.94)$ & $0.41(7.84)$ & $0.28(5.06)$ & $0.47(8.98)$ \\
\hline Unemployment & $\begin{array}{l}-0.18 \\
(-5.91)\end{array}$ & $\begin{array}{l}-0.24 \\
(-8.01)\end{array}$ & $\begin{array}{l}-0.20 \\
(-6.53)\end{array}$ & $\begin{array}{l}-0.23 \\
(-8.35)\end{array}$ & $\begin{array}{l}-0.02 \\
(-0.39)\end{array}$ & $\begin{array}{l}-0.18 \\
(-3.61)\end{array}$ & $\begin{array}{l}-0.01 \\
(-0.18)\end{array}$ & $\begin{array}{l}-0.13 \\
(-2.55)\end{array}$ \\
\hline $\begin{array}{l}\text { Real Exchange } \\
\text { Rate }\end{array}$ & $\begin{array}{l}-0.02 \\
(-1.70)\end{array}$ & $0.04(3.41)$ & $0.01(0.87)$ & $0.05(4.22)$ & $\begin{array}{l}-0.17 \\
(-3.66)\end{array}$ & $\begin{array}{l}-0.10 \\
(-2.09)\end{array}$ & $\begin{array}{l}-0.17 \\
(-3.50)\end{array}$ & $\begin{array}{l}-0.07 \\
(-1.48)\end{array}$ \\
\hline GIPSCI & $\begin{array}{l}-0.83 \\
(-1.52)\end{array}$ & $\begin{array}{l}-1.49 \\
(-2.99)\end{array}$ & $\begin{array}{l}-0.33 \\
(-0.61)\end{array}$ & $\begin{array}{l}-1.27 \\
(-2.55)\end{array}$ & $\begin{array}{l}-1.54 \\
(-2.36)\end{array}$ & $\begin{array}{l}-1.41 \\
(-2.19)\end{array}$ & $\begin{array}{l}-1.64 \\
(-2.49)\end{array}$ & $\begin{array}{l}-1.80 \\
(-2.84)\end{array}$ \\
\hline $\mathrm{N}$ & 532 & 532 & 532 & 532 & 241 & 241 & 241 & 241 \\
\hline
\end{tabular}

\footnotetext{
${ }^{11} 10 \%$ confidence interval; * $5 \%$ confidence interval; ** $1 \%$ confidence interval; $* * * 0.1 \%$ confidence interval.
} 


\section{References}

Afflatet, N. (2015). Public Debt and Borrowing - Are Governments Disciplined by Financial Markets? HSU Working Paper 156.

Allison, P. D. (1994). Using Panel Data to Estimate the Effects of Events. Sociological Methods \& Research, 23(2), 174-199. https://doi.org/10.1177/0049124194023002002

Alt, J. E., \& Lassen, D. D. (2006). Transparency, Political Polarization and Political Business Cycles in OECD Countries. American Journal of Political Science, 50(3), 530-550. https://doi.org/10.1111/j.1540-5907.2006.00200.x

Annett, A. (2006). Enforcement and the Stability and Growth Pact: How Fiscal Policy Did and Didn't Change under Europe's Fiscal Framework. IMF Working Paper 06/116. https://doi.org/10.5089/9781451863765.001

Baldwin, R., Beck, T., Bénassy-Quéré, A., Blanchard, O., Corsetti, G., de Grauwe, P., ... Weder di Mauro, B. (2015). Rebooting the Eurozone: Step I - agreeing a crisis narrative. CEPR Policy Insight No. 85.

Beetsma, R. M. W. J., \& Bovenberg, A. L. (2002). Strategic debt accumulation in a heterogeneous monetary union. European Journal of Political Economy, 19(1), 1-15. https://doi.org/10.1016/S0176-2680(02)00126-X

Bishop, G., Damrau, D., \& Miller, M. A. (1989). Market Discipline Can Work in the E. E. C. Monetary Union. London.

Brender, A., \& Drazen, A. (2005). Political budget cycles in new versus established democracies. Journal of Monetary Economics, 52(7), 1271-1295. https://doi.org/10.1016/j.jmoneco.2005.04.004

Brender, A., \& Drazen, A. (2008). How Do Budget Deficits and Economic Growth Affect Reelection Prospects: Evidence from a Large Panel of Countries. American Economic Review, 98(5), 2203-2220. https://doi.org/10.1257/aer.98.5.2203

Busemeyer, M. R. (2004a). Chasing Maastricht: The Effect of EMU on the Fiscal Performance of Member States. European Integration Online Paper 8.

Busemeyer, M. R. (2004b). The Effect of the European Economic and Monetary Union on the Fiscal Performance of the Member States. Working Paper presented on the conference of the DVPW, Cologne, 3-4. December 2004.

Buti, M., Franco, D., \& Ongena, H. (1998). Fiscal Discipline and Flexibility in EMU: The Implementation of the Stability and Growth Pact. Oxford Review of Economic Policy, 14(3), 81-97. https://doi.org/10.1093/oxrep/14.3.81

De Haan, J., Berger, H., \& Jansen, D. J. (2004). Why Did the Stability and Growth Pact Fail? International Finance, 7(2), 235-260. https://doi.org/10.1111/j.1367-0271.2004.00137.x

Edin, P. A., \& Ohlsson, H. (1991). Political Determinants of Budget Deficits: Coalition Effects versus Minority Effects. European Economic Review, 35, 1597-1603. https://doi.org/10.1016/0014-2921(91)90021-A

Feldstein, M. (2005). The Euro and the Stability Pact. NBER Working Paper 11249. https://doi.org/10.1016/j.jpolmod.2005.04.007

Frenkel, J. A., \& Goldstein, M. (1991). Monetary Policy in an Emerging European Economic and Monetary Union. IMF Staff Papers, 38(2), 356-373. https://doi.org/10.2307/3867103

Hagen, J. V. (2003). Fiscal Discipline and Growth in Euroland. ZEI Working Paper B 06/2003

Hagen, J. V., \& Strauch, R. R. (2001). Fiscal Consolidation: Quality, Economic Conditions, and Success. Public Choice, 109, 327-346. https://doi.org/10.1023/A:1013073005104

Hagen, J. V., \& Wolff, G. B. (2006). What Do Deficits Tell us about Debt? Empirical Evidence on Creative Accounting with Fiscal Rules in the EU. Journal of Banking and Finance, 30(12), 3259-3279.

https://doi.org/10.1016/j.jbankfin.2006.05.011

Heinen, N. (2009). Schuldenspirale oder Exit-Strategie - Was kann der Stabilitäts- und Wachstumspakt leisten? Deutsche Bank Research, September 30, 2009.

Ioannou, D., \& Stracca, L. (2011). Have Euro Are and EU Economic Governance Worked? Just the Facts. ECB Working Paper Series No. 1344.

Issing, O. (2008). Der Euro [The Euro]. Munich. https://doi.org/10.15358/9783800643813

Issing, O. (2012). Wie wir den Euro retten und Europa stärken [How to save the Euro and strengthen Europe]. Kulmbach.

Jong-A-Pin, R., Sturm, J. E., \& de Haan, J. (2012). Using Real-Time Data to Test for Political Budget Cycles. CESifo Working Paper No. 3939. https://doi.org/10.2139/ssrn.2150138 
Kydland, F. E., \& Prescott, E. C. (1977). Rules rather than Discretion: The Inconsistency of Optimal Plans. Journal of Political Economy, 85(3), 473-492. https://doi.org/10.1086/260580

Lane, T. D. (1993). Market Discipline. IMF Staff Papers, 40(1), 53-88. https://doi.org/10.2307/3867377

Lehment, H. (2002). European fiscal policies under the stability pact - some first insights. Kieler Arbeitspapiere No. 1098. https://doi.org/10.2139/ssrn.306701

Moog, S., \& Raffelhüschen, B. (2011). Tatsächliche Staatsverschuldung in Europa im Vergleich. Stiftung Marktwirtschaft Nr. 115, December 2011.

Perotti, R., \& Kontopoulos, Y. (2002). Fragmented Fiscal Policy. Journal of Public Economics, 86, 191-222. https://doi.org/10.1016/S0047-2727(01)00146-3

Roubini, N., \& Sachs, J. D. (1989). Political and Economic Determinants of Budget Deficits in the Industrialized Countries. European Economic Review, 33, 903-938. https://doi.org/10.1016/0014-2921(89)90002-0

Sinn, H. W. (2012). The TARGET Trap. München. https://doi.org/10.3139/9783446433915

Sinn, H. W. (2014). Austerity, Growth and Inflation: Remarks on the Eurozone's Unresolved Competitiveness Problem. The World Economy (2014). https://doi.org/10.1111/twec.12130

Starbatty, J. (2013). Crime Scene Euro. Vienna, Berlin, Munich.

Volkerink, B., \& de Haan, J. (2000). Fragmented Government Effects on Fiscal Policy: New Evidence. Groningen.

Woolridge, J. (2002). Econometric Analysis of Cross Section and Panel Data (Second Edition). Cambridge: MIT Press.

Woolridge, J. (2012). Introductory Econometrics: A Modern Approach (Fifth Edition). Madison: South Western.

\section{Copyrights}

Copyright for this article is retained by the author(s), with first publication rights granted to the journal.

This is an open-access article distributed under the terms and conditions of the Creative Commons Attribution license which permits unrestricted use, distribution, and reproduction in any medium, provided the original work is properly cited. 